\title{
Mapping nursing goals of an Intensive Care Unit to the Nursing Outcomes Classification
}

\author{
Tânia Couto Machado Chianca ${ }^{1}$ \\ Patrícia de Oliveira Salgado ${ }^{2}$ \\ Juliana Peixoto Albuquerque ${ }^{3}$ \\ Camila Claudia Campos ${ }^{4}$ \\ Meire Chucre Tannure ${ }^{5}$ \\ Flávia Falci Ercole ${ }^{6}$
}

Aim: to analyze whether nursing goals formulated for nursing diagnoses can be mapped to nursing outcomes classification and to identify the scales most appropriate to the outcomes mapped. Method: a descriptive study was developed in an intensive care unit. Data collection involved extraction of goals in 44 medical records, content standardization, cross-mapping to the outcomes, identification of appropriated scales and validation. Descriptive analysis and agreement with the cross-mapping process were performed. Results: nursing goals (59) were mapped to (28) different outcomes, with agreement of $83 \%$ in the mapping process. All goals were mapped to outcomes, which allows to affirm that these outcomes contemplates the goals elaborated to patient care. Conclusion: these results favor the inclusion of outcomes and scales validated in the planning and evaluation phases of the nursing process of a software in construction.

Descriptors: Nursing; Nursing Process; Intensive Care Units; Validation Studies; Nursing Assessment. \footnotetext{
Brazil.

${ }^{3}$ RN, PhD Consult, Brazil.

${ }^{1}$ PhD, Full Professor, Escola de Enfermagem, Universidade Federal de Minas Gerais, Brazil.

2 RN, Hospital Municipal Odilon Behrens, Brazil. Doctoral Student, Escola de Enfermagem, Universidade Federal de Minas Gerais,

${ }^{4}$ Undergraduate student in Nursing, Escola de Enfermagem, Universidade Federal de Minas Gerais, Brazil.

5 PhD, Professor, Pontifícia Universidade Católica, Campus Coração Eucarístico, Belo Horizonte, Brazil.

${ }^{6}$ PhD, Adjunct Professor, Escola de Enfermagem, Universidade Federal de Minas Gerais, Brazil. 


\title{
Mapeamento de metas de enfermagem de uma Unidade de Terapia Intensiva por meio da Classificação de Resultados de Enfermagem
}

Objetivo: analisar se metas formuladas, a partir de diagnósticos de enfermagem, podem ser mapeadas por meio de resultados e identificar escalas apropriadas aos resultados mapeados. Método: estudo descritivo, realizado em unidade de terapia intensiva. A coleta envolveu extração das metas registradas em 44 prontuários, normalização de conteúdo, mapeamento de resultados, identificação das escalas apropriadas e validação. Análise descritiva e de concordância com o processo de mapeamento foram procedidas. Resultados: metas de enfermagem (59) foram mapeadas por diferentes resultados (28), com concordância de $83 \%$ no processo de mapeamento. Todas as metas foram mapeadas através de resultados, o que permite afirmar que esses contemplam as metas elaboradas para os pacientes cuidados. Conclusão: os achados favorecem a inclusão de resultados e escalas nas etapas de planejamento e avaliação em um software com o processo de enfermagem em construção.

Descritores: Enfermagem; Processos de Enfermagem; Unidades de Terapia Intensiva; Estudos de Validação; Avaliação em Enfermagem.

\section{Identificación de metas de enfermería de una Unidad de Cuidados Intensivos a la Clasificación de Resultados de Enfermería}

\begin{abstract}
Objetivo: analizar si en las metas formuladas desde diagnósticos de enfermería pueden ser identificados resultados y escalas apropiadas a los resultados identificados. Método: estudio descriptivo realizado en unidad de terapia intensiva. La colecta envolvió extracción de las metas registradas en 44 prontuarios, normalización de contenido, identificación de resultados, de las escalas apropiadas y validación. Análisis descriptivo y de concordancia con el proceso de identificación fueron procedidas. Resultados: En las metas de enfermería (59) fueron identificados diferentes resultados (28), con concordancia del $83 \%$ en el proceso de identificación. En todas las metas fueron identificados resultados, lo que permite afirmar que ésos contemplan las metas elaboradas para los pacientes atendidos. Conclusión: los hallazgos favorecen la inclusión de resultados y escalas en las etapas de planificación y evaluación en un software con el proceso de enfermería en construcción.
\end{abstract}

Descriptores: Enfermería; Procesos de Enfermería; Unidades de Cuidados Intensivos; Estudios de Validación; Evaluación en Enfermería.

\section{Introduction}

Nursing care is considered essential for the treatment of the majority of patients, however, it is still not very visible or recognized. One reason for the invisibility of nursing in healthcare is the number of nurses who do not document in the medical records of patients the problems identified, the planning and the actions they perform to minimize/address the needs diagnosed. The low amount of data recorded in the patient records, as well as its low quality, is observed in the practice. This registration need to be standardized and improved, both in terms of presentation, as well as in the structure and content of the nursing annotations ${ }^{(1)}$. There are faults in the language and the identification information, in the use of technical terminology and problems in the accuracy, brevity, legibility and identification of information ${ }^{(2)}$. This deficiency has been taking place despite legislation ${ }^{(3)}$ which determines that the deployment of the Nursing Care Systematization (NCS) must occur throughout the national territory and that the steps of the Nursing Process (NP) must be recorded in the clinical records 
of the patients. It should, however, be noted that some Brazilian nurses recognize, utilize and have demonstrated the advantages of the registration of the steps of the NP and of the use of standardized nursing languages in the clinical practice ${ }^{(4-5)}$. Others have shown its use in nursing research (identification, mapping and validation studies) ${ }^{(6-9)}$.

The use of recognized classification systems, such as nursing diagnoses, interventions and outcomes, collaborate with adoption of standardized languages that can help give visibility to the nurses work. In nursing, to classify means to develop a language that can describe the clinical judgments, what they do, what they diagnose and what they usually evaluate, which are the responsibility of the nurse. The terms used in nursing are grouped based on their similarities (10). Some classifications are recognized and used, such as the NANDA International (NANDA-I)(11), the Nursing Interventions Classification (NIC) ${ }^{(12)}$ and the Nursing Outcomes Classification (NOC)(13). The NOC was developed by a team of researchers from the College of Nursing of the University of Iowa, in the United States of America (USA). It is a systematic organization of the nursing outcomes obtained with patients which are sensitive to the nursing interventions ${ }^{(13)}$. The NOC outcomes are measurable items of the patient, family and community. They may be a state, behavior or perception and must be determined after the establishment of a nursing diagnosis (ND). They are heavily influenced by the nursing interventions ${ }^{(13)}$. The NOC is useful for evaluating the effectiveness of the nursing care. It provides a standardized language to describe what outcomes nurses can achieve with the patients, families and communities.

Currently, there are few health databases of the Brazilian population that include nursing data. However, with the growing demands for improved quality of care and decreased hospital costs in Brazil, it is imperative that nurses document their practice and establish the value of their work in healthcare. Thus, it becomes relevant to perform studies that favor the development of nursing databases to quantify the quality of healthcare (effectiveness) in Brazil. Studies to identify the usefulness of standardized nursing languages (diagnoses, interventions and outcomes) are important in that they collaborate in the description of the nursing practice in healthcare services, among these the adult Intensive Care Unit (ICU). Also, they can contribute to the inclusion of these data in information systems and databases that will be used to establish the quality of nursing care.
In an Adult ICU of Belo Horizonte city, Minas Gerais (MG), the steps of the NP have been implemented since 2006. However, unlike ND prepared for patients hospitalized in this service using the NANDA-I(11) as a reference, nursing outcomes/goals for the diagnoses established are formulated based on the experience and knowledge of the nurses, supported by textbooks of the nursing area, with no classification of nursing outcomes being used. Thus, the question is: can the terms contained in the nursing goals formulated for the NANDA-I nursing diagnoses be mapped to the NOC?

This study is justified considering that the use of a set of outcomes/indicators enables the progress or lack thereof to be measured in relation to the prescribed nursing care. Furthermore, it is intended that the NOC will be integrated to a piece of software under development to assist in implementing the NCS in adult ICUs. This study aims to analyze the nursing goals documented in the patient records of patients hospitalized in an adult ICU of Belo Horizonte; to map the terms contained in the goals identified to the NOC; to identify the NOC scales that were most appropriate regarding the outcomes mapped and to validate the mapping process performed.

\section{Methodology}

This descriptive study was performed in the ICU of a private hospital in Belo Horizonte with a 10 bed capacity. The study population consisted of 494 medical records of patients hospitalized in the ICU in the period $1^{\text {st }}$ September 2008 to $30^{\text {th }}$ September 2009. The sample consisted of 44 medical records ( $9 \%$ of the population), estimated as being representative of the 494 patient records through the permutation resampling method ${ }^{(14)}$. The free software $\mathrm{R}^{(15)}$ was used to construct the algorithm.

The study was composed of 4 steps: The first step consisted of analyzing the patient records to identify the nursing goals. All the nursing goals in the period of hospitalization of the patient in the ICU were considered. This choice was made due to the strong possibility of change in the clinical status of the patients during this period. In the second step the standardization of the contents of the nursing goals was performed using the Excel for Windows program. The standardization consisted of correction of the spelling and verb tenses, and the standardization of the synonyms and pseudoterminological expressions. These expressions are considered "junk terminology", being defined as 
elements which occur in casual speech, but that do not designate particular concepts(16). The third step was composed of mapping the terms contained in the identified nursing goals to the outcomes listed in the NOC. Furthermore, the NOC scales were identified that were most appropriate regarding the outcomes mapped. The mapping was performed using the methodological procedure termed "cross mapping", which consists of connecting the words with similar or identical meanings, using inductive and deductive strategies by means of a decision-making process ${ }^{(17)}$. This method involves the use of rules that can be outlined throughout the study. These rules should be based on characteristics of the structure of the data collected and of the classification adopted $^{(6)}$. In this study we used the model, with adaptations of the rules, to connect the terms contained in the nursing goals with the labels of the NOC outcomes. The fourth step consisted of the validation of the cross mapping performed and of the NOC scales chosen. Primarily the validation occurred through the analysis and confirmation of the mapping by the researchers from a Nursing Classifications study center. Then, the mapping confirmed in the first analysis was validated by a group of expert nurses in a workshop context.

The sample of expert nurses was selected by convenience through individual invitation and based on the criteria of Fehring ${ }^{(18)}$ adapted to the area of intensive care and nursing classification. All the invited nurses answered the questionnaire adapted from the criteria of Fehring ${ }^{(18)}$ and those who scored more than five were selected to participate in the validation workshop. After the selection, the group was composed of six nurses who agreed to participate in the study by signing the Terms of Free Prior Informed Consent. The workshops technique was chosen as this is a way to collect research data in a structured manner, focused around a central question that the group proposes to develop. It does not restrict the subjects to rational reflection, but involves them in an integral way, considering their ways of thinking, feeling and acting, creating learning spaces ${ }^{(19)}$.

The workshop was structured in three moments: in the first, the study proposal was presented followed by the delivery of an instrument composed of the set of nursing goals by nursing diagnosis label of the NANDA-I extracted from the clinical records and the cross mapping of the NOC outcomes performed. The nurses were asked to give their opinion regarding the concordance with the cross mapping performed. In the second moment of the workshop the NOC scales chosen and the definitions elaborated were presented, and the nurses gave their opinions regarding the concordance with the process. Finally (third moment), after the individual recordings, the nurses were invited to express their opinions in the group in order to foster a discussion based on the analysis of their impressions.

Descriptive analysis of the demographic data of the 44 patients whose clinical records were included in the sample and of the nurses (age, gender, year of graduation) who validated the nursing goals was carried out. To evaluate the degree of concordance of the nurses with the mapping performed, the partial and total concordance index was determined for each nursing target mapped using the formula Concordance Index $(\mathrm{CI})=($ No. of concordances/No. of concordances + No. of disconcordances) $\times 100^{(20)}$. The total concordance consisted of the sum of all the concordances about nursing outcomes, scales and definitions, divided by the sum of the concordances and disagreements of outcomes, scales and definitions multiplied by 100 . The index of $70 \%$ was adopted as the minimum acceptable level of concordance to be obtained from the experts in the validation process.

The nurse who presented the higher scores according to Fehring model adaptation ${ }^{(18)}$ was considered as the gold standard. This nurse obtained a score of 14 points. The study was approved by the Research Ethics Committee (REC) of the Federal University of Minas Gerais (REC Protocol No. 315/09).

\section{Results}

Among the 44 patients who comprised the sample $30(68 \%)$ were female. Their ages ranged between 28 and 93 years, with the mean age being 64 years, the median 66.5 years, and a standard deviation of 17.5 years. There was a concentration of elderly patients $(68.3 \%)$, with chronic diseases. In the patient records analyzed 59 nursing goals were proposed for the 32 NANDA-I nursing diagnoses labels formulated. Figure 1 presents the nursing diagnoses formulated and the respective nursing goals established. 


\begin{tabular}{|c|c|}
\hline Nursing diagnoses & Nursing goals \\
\hline Breastfeeding interrupted & Breast engorgement will not be presented while hospitalized in the sector. \\
\hline Anxiety & Anxiety levels will be alleviated during the hospitalization. \\
\hline Acute confusion & Pattern of confusion will improve within 2 days. \\
\hline Chronic Confusion & Guidance will be frequently provided regarding time and space. \\
\hline Constipation & Regular intestinal movements will be restored within 2 days. \\
\hline Decreased cardiac output & Cardiac output will be optimized within 24 hours. \\
\hline Self care bathing/hygiene deficit & Bathing/hygiene will be maintained while the self care deficit remains. \\
\hline Self care intimate hygiene deficit & Adequate intimate hygiene will be maintained while the self-care deficit remains. \\
\hline Self-care feeding deficit & Oroenteric tube feeding will be performed while the feeding deficit remains. \\
\hline \multirow{4}{*}{ Ineffective airway clearance } & $\begin{array}{l}\text { Airway patency will be maintained while remaining without expectorate tracheal secretion } \\
\text { conditions. }\end{array}$ \\
\hline & Airway patency will be maintained while sedated and intubated. \\
\hline & $\begin{array}{l}\text { Clear airways will be maintained while tracheostomized and unable to expectorate tracheal } \\
\text { secretions. }\end{array}$ \\
\hline & $\begin{array}{l}\text { Bronchial toilet will be performed whenever there is pulmonary rhonchi and excessive } \\
\text { secretions, maintaining clear airways. }\end{array}$ \\
\hline Acute pain & Cessation of pain will be presented within 24 hours. \\
\hline Chronic Pain & Pain control will be maintained while hospitalized in the sector. \\
\hline Impaired urinary elimination & $\begin{array}{l}\text { Bladder emptying in up to } 6 \text { hours will be presented; urinary retention will not be presented } \\
\text { while hospitalized in this sector. }\end{array}$ \\
\hline Hyperthermia & An improved thermal curve will be presented within 2 days. \\
\hline \multirow{5}{*}{ Impaired skin integrity } & Lesion improvement will be presented after 7 days. \\
\hline & Skin integrity will be recovered within 26 days. \\
\hline & Cicatrization will be presented within 30 days and there will not be any other lesions. \\
\hline & Skin around the device will be maintained intact while this remains. \\
\hline & $\begin{array}{l}\text { Abdominal and operative wound tissue integrity will improve within } 13 \text { days and the condition } \\
\text { of tissue around the insertion of invasive devices will be maintained while these remain. }\end{array}$ \\
\hline Impaired tissue integrity & $\begin{array}{l}\text { Abdominal and operative wound tissue integrity will improve within } 3 \text { days and the condition } \\
\text { of tissue peripheral to the insertion of invasive devices will be maintained while these remain. }\end{array}$ \\
\hline \multirow{3}{*}{ Impaired bed mobility } & $\begin{array}{l}\text { Movement every } 2 / 2 \text { hours, hydration protection and decompression of the bony } \\
\text { prominences will be performed while immobile in the bed. }\end{array}$ \\
\hline & Mobilization in the bed will be performed while hospitalized in the sector. \\
\hline & $\begin{array}{l}\text { Mobilization in the bed will be performed every } 2 / 2 \text { hours and when required while } \\
\text { hospitalized in this ICU. }\end{array}$ \\
\hline Unbalanced nutrition: less than the body requirements & Adequate nutritional status will be restored within 10 days. \\
\hline $\begin{array}{l}\text { Ineffective breathing } \\
\text { pattern }\end{array}$ & Effective breathing pattern will be restored within 24 hours. \\
\hline Ineffective renal perfusion & Adequate renal tissue perfusion will be reestablished within 2 days. \\
\hline Interrupted family processes & Integral care will be provided, including social assistance, while hospitalized in the sector. \\
\hline Ineffective protection & $\begin{array}{l}\text { Normal blood profile will be restored within } 5 \text { days. } \\
\text { Platelet count above } 140,000 \text { will be reestablished within } 96 \text { hours } \\
\text { Bleeding will not be presented while hospitalized and global levels of leukocytes will improve } \\
\text { within } 72 \text { hours. } \\
\text { Leukocytes will be reduced to normal values within } 24 \text { hours. }\end{array}$ \\
\hline Dysfunctional ventilator weaning response & $\begin{array}{l}\text { Will remain on mechanical ventilation until ventilator weaning conditions are presented. } \\
\text { Adequate respiratory capacity for the performance of ventilator weaning will be presented } \\
\text { within } 72 \text { hours. }\end{array}$ \\
\hline Risk for aspiration & $\begin{array}{l}\text { Gastric and/or oropharyngeal contents will not be aspired while drowsy } \\
\text { Gastric and/or oropharyngeal contents will not be aspired while receiving enteral nutrition and } \\
\text { having a decreased level of consciousness. }\end{array}$ \\
\hline Risk for constipation & $\begin{array}{l}\text { Constipation will not be presented while hospitalized in this ICU. } \\
\text { Control to prevent constipation will be performed while hospitalized in the sector. }\end{array}$ \\
\hline Risk for neurovascular dysfunction & Neurovascular dysfunction will not develop while the device remains. \\
\hline Risk for unstable blood glucose level & $\begin{array}{l}\text { Glycemic control will be performed while hospitalized in the sector. } \\
\text { The glucose level will be maintained during the stay in the ICU. }\end{array}$ \\
\hline Risk for infection & $\begin{array}{l}\text { Infection related to invasive devices will not be presented while hospitalized in the sector. } \\
\text { Infection related to invasive procedures and surgical wounds will not develop while } \\
\text { hospitalized in the ICU. } \\
\text { Infection related to peripheral venous access will not develop while hospitalized; injuries } \\
\text { while hospitalized in this ICU. } \\
\text { Decubitus change every } 2 / 2 \mathrm{~h} \text {, protection, hydration and decompression of the bony } \\
\text { prominences will be performed at integral times so that new lesions do not occur, while } \\
\text { hospitalized in the sector. } \\
\text { Skin integrity will be maintained while hospitalized in the ICU. }\end{array}$ \\
\hline
\end{tabular}

(The Figure 1 continue in the next page...) 


\begin{tabular}{|l|l|}
\hline \multicolumn{1}{|c|}{ Nursing diagnoses } & \multicolumn{1}{c|}{ Nursing goals } \\
\hline Risk for impaired skin integrity & $\begin{array}{l}\text { New lesions will not develop while hospitalized in this ICU } \\
\text { Decubitus change every } 2 / 2 \mathrm{~h} \text {, protection, hydration and decompression of the bony } \\
\text { prominences will be performed at integral times so that new lesions do not occur, while } \\
\text { hospitalized in the sector. } \\
\text { Skin integrity will be maintained while hospitalized in the ICU. }\end{array}$ \\
\hline Risk for relocation stress syndrome & $\begin{array}{l}\text { Relocation stress syndrome will not be presented while hospitalized in the sector. } \\
\text { Attention and guidance will be provided so as not to introduce stress syndrome while } \\
\text { hospitalized in the ICU. }\end{array}$ \\
\hline Impaired gas exchange & $\begin{array}{l}\text { Effective exchange of gases will be presented within } 3 \text { days. } \\
\text { Improved oxygenation/perfusion will be presented within } 2 \text { days } \\
\text { Arterial gas and radiological improvements will be presented within } 24 \text { hours. } \\
\text { Arterial carbon dioxide level will improve within } 24 \text { hours. }\end{array}$ \\
\hline Fluid Volume Excess & $\begin{array}{l}\text { An adequate volume of fluids will be restored within } 5 \text { days. } \\
\text { An adequate volume of extravascular fluids will be restored within } 7 \text { days. }\end{array}$ \\
\hline
\end{tabular}

Figure 1 - Nursing diagnoses and goals documented in the patient records. Belo Horizonte, MG, Brazil, 2011

\section{Mapping of the nursing goals to the NOC outcomes and suggestion of scales}

The 59 nursing goals identified were mapped to the nursing outcomes proposed from the NOC. The terms contained in the goals were mapped to 28 different $(8.7 \%)$ outcomes established from the NOC. Table 1 presents the domains, classes and NOC outcomes mapped and the frequency with which they were used.

Table 1 - Domains, Classes and NOC Outcomes mapped. Belo Horizonte, MG, Brazil, 2011

\begin{tabular}{|c|c|c|c|c|}
\hline Domains & Classes & Outcomes & $\mathbf{n}$ & $\%$ \\
\hline \multirow[t]{17}{*}{ Physiological health } & \multirow[t]{2}{*}{ Tissue integrity } & Wound healing: secondary intention & 5 & 7,4 \\
\hline & & Tissue integrity: skin and mucous membranes & 4 & 5,9 \\
\hline & \multirow[t]{5}{*}{ Cardiopulmonary } & Blood coagulation & 5 & 7,4 \\
\hline & & Respiratory status: gas exchange & 5 & 7,4 \\
\hline & & Respiratory status: airways patency & 4 & 5,9 \\
\hline & & Respiratory status: ventilation & 2 & 2,9 \\
\hline & & Cardiac pump effectiveness & 1 & 1,5 \\
\hline & \multirow[t]{3}{*}{ Elimination } & Gastrointestinal function & 3 & 4,4 \\
\hline & & Urinary elimination & 1 & 1,5 \\
\hline & & Kidney Function & 1 & 1,5 \\
\hline & \multirow[t]{2}{*}{ Nutrition } & Breastfeeding: Weaning & 1 & 1,5 \\
\hline & & Nutritional status: nutrient intake & 1 & 1,5 \\
\hline & Immune response & Immune status & 4 & 5,9 \\
\hline & Fluid and electrolytes & Fluid balance & 2 & 2,9 \\
\hline & Neurocognitive & Cognitive orientation & 2 & 2,9 \\
\hline & Therapeutic response & Blood glucose level & 1 & 1,5 \\
\hline & Metabolic regulation & Thermoregulation & 1 & 1,5 \\
\hline \multirow[t]{4}{*}{ Functional health } & Mobility & Mobility & 3 & 4,4 \\
\hline & Self Care & Self Care: bathing & 1 & 1,5 \\
\hline & & Self Care: hygiene & 1 & 1,5 \\
\hline & & Self Care: intimate hygiene & 1 & 1,5 \\
\hline \multirow[t]{3}{*}{ Health Knowledge and Behavior } & \multirow[t]{3}{*}{ Risk and safety control } & Risk control & 9 & 13,2 \\
\hline & & Pain control & 2 & 2,9 \\
\hline & & Aspiration prevention & 2 & 2,9 \\
\hline \multirow[t]{3}{*}{ Psychosocial health } & Psychosocial adaptation & Acceptance: health status & 2 & 2,9 \\
\hline & Social interaction & Social support & 1 & 1,5 \\
\hline & Psychosocial well-being & Anxiety level & 1 & 1,5 \\
\hline Total & & & 67 & 100 \\
\hline
\end{tabular}

The NOC taxonomy is composed by 7 domains and 31 classes. It can be observed that the NOC nursing outcomes mapped are contemplated in 4 (57\%) domains and $15(47 \%)$ of the NOC classes. The greatest number of NOC outcomes mapped, 17 (60\%) are found in the Physiological health domain. Another 4 (18\%) 
are found in the Functional health domain distributed in the mobility and self-care classes. A total of 3 nursing outcomes were found in the Health knowledge and behavior domain, in the class risk and safety control. The Psychosocial Health domain also had 3 outcomes distributed in the psychosocial adaptation, social interaction and psychosocial well-being classes. From the outcomes mapped NOC scales were proposed, with six $(54.5 \%)$ different scales being selected from the 11 existing measurement scales. Figure 2 also presents examples of the mapping process performed.

\begin{tabular}{|l|l|l|}
\hline \multicolumn{1}{|c|}{ Nursing Goals } & \multicolumn{1}{c|}{ NOC Outcomes } & NOC Scales \\
\hline Anxiety levels will be alleviated during the hospitalization. & Anxiety level & Severe to none \\
\hline The pattern of confusion will improve within 2 days. & Cognitive orientation & Severely compromised to not compromised \\
\hline Regular intestinal movements will be restored within 2 days. & Gastrointestinal function & Severely compromised to not compromised \\
\hline Cardiac output will be optimized within 24 hours. & Cardiac pump effectiveness & Severely compromised to not compromised \\
\hline $\begin{array}{l}\text { Feeding by OET will be performed while the feeding deficit } \\
\text { remains. }\end{array}$ & Nutritional status & $\begin{array}{l}\text { Serious deviation from the normal parameters to } \\
\text { Without deviation from the normal parameters }\end{array}$ \\
\hline
\end{tabular}

Figure 2 - Nursing outcomes and NOC scales proposed for the nursing goals formulated - Example of cross-mapping

\section{Validation of the nursing goals mapped and definition of the scales}

All the nurses who participated in the validation process of the nursing goals mapped worked and lived in Belo Horizonte, MG and were female (Table 2).

Table 2 - Characteristics of the sample of expert nurses. Belo Horizonte, MG, Brazil, 2011

\begin{tabular}{llc}
\hline \multicolumn{1}{c}{ Characteristics of the sample } & N & $\%$ \\
\hline Female & 6 & 100 \\
Total Professional Experience & & \\
0 to 5 years & 4 & 66.0 \\
15 to 20 years & 1 & 17.0 \\
20 to 30 years & 1 & 17.0 \\
Highest qualification obtained & & \\
Specialist & 3 & 50.0 \\
MSc & 1 & 17.0 \\
PhD & 2 & 33.0 \\
Length of practice in Intensive Care Unit & & \\
1 to 5 years & 5 & 83.0 \\
Without experience & 1 & 17.0 \\
\hline
\end{tabular}

The majority of the expert nurses had up to 5 years experience, working from one to five years in the intensive care area (five nurses), three of the nurses were specialists in the area, one obtained a Master's degree and two PhDs. A concordance index of $86 \%$ was obtained regarding the NOC outcomes mapped; $78 \%$ regarding the NOC scales suggested; and $90 \%$ regarding the definitions proposed for the suggested scales, since conceptual and operational definitions for the scales are not established in this classification. A total concordance in the mapping of outcomes process, scales and definitions was performed yielding an index of $83 \%$.

\section{Discussion}

The majority (68.3\%) of the patients concentrated in the age group of people aged greater than or equal to 60 years. The mean age of ICU patients has increased in recent years and will further increase with the aging of the general population. In Western countries, the percentage of individuals over 65 years of age represents $18 \%$ of the general population, accounting for $45.5 \%$ of hospital admissions ${ }^{(21)}$. Cross mapping is a process of comparing data by using words with identical or similar meanings ${ }^{(8)}$. Studies have shown the validity of the methodology in comparing non-standardized nursing languages to uniform nursing classification terminologies identifying similarities between the terms ${ }^{(6-9,22)}$.

The NOC "Risk control" was the most frequent. It can be observed that nine $(13.2 \%)$ of the 29 different NOC outcomes ${ }^{(13)}$ were employed, followed by the NOCs "Wound cicatrization: secondary intention", "Blood Coagulation" and "Respiratory status: gas exchange", all with a score of 5 (7.4\%). The NOC "Risk control" is allocated in the Health knowledge and behavior(13) domain, despite the predominance of the NOCs present in the Physiological health domain. A similar study conducted in two ICUs of Iowa, in which 42 NOC outcomes were collected, showed that the majority were found in the Physiological health domain, corroborating the results of the present study. The principle NOCs found in common were: "Tissue integrity: skin and mucous membranes", "Respiratory status: Ventilation" and "Nutritional status: nutrient intake"(23). The NOC "Risk control" is defined as the "actions to eliminate or reduce actual, personal, and modifiable health threats"(13) which justifies this NOC having been the one more frequently 
used in the mapping process. It reflects the profile of critical patients treated in an ICU. These are severe patients who require continuous nursing care.

All the nursing goals formulated were mapped to NOC outcomes, which allow it to be affirmed that, despite the use of the NOC classification being recent, its NOCs include the nursing goals elaborated by the nurses for the patients they care for and can be used to represent the nursing practice in the context of an ICU. When the different NOC outcomes used in crossmapping are analyzed and their relationship with the domains of this classification ${ }^{(13)}$, it is verified that these comprehend 4 of the 7 domains, with the majority being located in the Physiological health domain (17 - 60\%) followed by the Functional health domain ( $5-18 \%$ ). This data indicates the tendency of nurses working in adult ICUs to formulate nursing diagnoses and consequently to establish outcomes to be achieved focused on the psychobiological needs of the individuals.

From the outcomes mapped, six (54.5\%) different scales were selected from the 11 present in the NOC. The NOC scales are of the Likert type with five points and permit a characterization of the state of health of the patient at a more concrete level which is reproducible over a continuum ${ }^{(13)}$. The mapping of the NOC nursing goals and its validation performed in the present study contribute to the systematization and standardization of the nomenclature used in the practice of evaluation of the nursing care provided. This contribution corroborates with studies that consider the application of the steps of the NP extremely important, especially the evaluation of the outcomes. The use of isolated steps, such as when employing only the nursing diagnosis, is insufficient to mitigate or solve all the needs of the patients(24) and to give visibility to the nursing work performed. The scientific literature related to the use of the $\mathrm{NOC}^{(13)}$ is recent and mostly North American. This finding demonstrates the need to develop more of these studies in Brazil in order to incorporate the nomenclature into the nursing practice reality ${ }^{(25)}$.

\section{Conclusions}

The terms contained in the nursing goals for the range of outcomes to the nursing diagnoses were identified and mapped to the NOC and NOC scales were suggested for the outcomes mapped. The mapping was considered adequate as it obtained acceptable levels of concordance regarding the NOC outcomes mapped, the NOC scales suggested and the definitions proposed for the scales suggested. A total concordance index of $83 \%$ regarding the mapping process performed was achieved. Thus, it can be affirmed that the mapping process was validated by expert nurses since a concordance index greater than $70 \%$ was obtained.

These results favor the introduction of NOC outcomes mapped to goals that nurses have previously documented in the patient records and the respective scales suggested for inclusion in the planning stage of nursing care in a piece of systematization of nursing care software being implemented in the unit. These NOC outcomes and its scales can be used in the evaluation phase of nursing care since they generate quality of care indicators, which promotes the determination of the effectiveness of the care provided by nurses in hospital inpatient units.

\section{References}

1. Setz VG, D'Innocenzo M. Evaluation of the quality of nursing documentation though the review of patient medical records. Acta Paul enferm. [periódico na Internet]. 2009 Jun [citado 2012 Mar 12]; 22(3):313-7. Disponível em: http://www.scielo.br/scielo.php?script=sci_ arttext\&pid =S0103-1002009000300012\&lng =pt http://dx.doi.org/10.1590/S0103-21002009000300012 2. Matsuda LM, Silva DMP, Évora YDM, Coimbra JAH. Anotações/registros de enfermagem: instrumento de comunicação para a qualidade do cuidado? Rev Eletr Enferm. [periodico na Internet]. 2006 [acesso 12 mar 2012]; 8(3):415-21. Disponível em: http://www.fen. ufg.br/revista/revista8_3/v8n3a12.htm

3. Conselho Federal de Enfermagem (COFEN (BR). Resolução n 358/2009 de outubro de 2009. Dispõe sobre a Sistematização da Assistência de Enfermagem e a implementação do Processo de Enfermagem em ambientes, públicos ou privados, em que ocorre o cuidado profissional de Enfermagem e dá outras providências [internet]. 15 out 2009. [acesso 1 jun 2011]. Disponível em: http://site.portalcofen.gov.br/node/4384

4. Tannure MC, Chianca TCM. Terminology bank of nursing language for the adult intensive care unit. Rev Enferm UFPE on line. [periódico na Internet]. 2009 July/ Sep [acesso 10 mar 2012]; 3(2):786-8. Disponível em: http://www.ufpe.br/revistaenfermagem/index.php/ revista/article/view/197/pdf_938

5. Tannure MC, Bedran T, Ercole FF, Sampaio MM, Werli A, Silva CC, Andrade CR, Chianca TCM. Mapeamento dos termos da CIPE - versão 1.0, com os registros de enfermeiros de uma UTI Adulto de Belo Horizonte. Rev 
Enferm UFPE on line. [periódico na Internet]. 2009 July/ Sept [acesso 26 mar 2012]; 3(2):534-40. Disponível em: http://www.ufpe.br/revistaenfermagem/index. php/revista/article/view/161/pdf_903

6. Moorhead S, Delaney C. Mapping nursing intervention data into the nursing interventions classification (NIC): process and rules. Nurs Diagn. 1997;8(4):137-44.

7. Chianca TCM. Mapeando ações de enfermagem da CIPESC para as intervenções da NIC. Rev Bras Enferm. 2003;56(5):513-8.

8. Lucena AF, Barros ALBL. Mapeamento cruzado: uma alternativa para a análise de dados em enfermagem. Acta Paul Enferm. 2005;18(1):82-8.

9. Salgado PO, Chianca TCM. Identification and mapping of the nursing diagnoses and actions in an Intensive Care Unit. Rev. Latino-Am. Enfermagem. July/Aug 2011;19(4):928-35.

10. Chianca TCM. A pesquisa em enfermagem e os sistemas de classificação dos elementos da prática. In: Tannure MC, Gonçalves AMP. Sistematização da Assistência de Enfermagem: Guia Prático. 2. ed. Rio de Janeiro (RJ): Guanabara Koogan; 2010. 298 p.

11. North American Nursing Diagnosis Association. Diagnósticos de enfermagem da NANDA: definições e classificação 2009-2011. Porto Alegre: Artmed; 2009. $456 \mathrm{p}$.

12. Bulechek GM, Dochterman JMcC, Butcher HK. NIC - Classificação das intervenções de enfermagem. 5.ed. Rio de Janeiro: Elsevier; 2010. 901 p.

13. Johnson M, Maas M, Moorhead S. Classificação dos resultados de enfermagem (NOC). 4. ed. Porto Alegre: Artmed; 2010. 906 p.

14. Good PI. Permutation Tests: a pratical guide to resampling methods for testing hyphoteses. 2nd. ed. New York: Springer-Verlag; 1994. (Springer series in statistics)

15. Ross SM. Simulation. 4th. Ed. San Diego: Elsevier; 2006.

16. Pavel S, Nolet D. Manual de terminologia. Canadá: Public Words and Govermment Services; 2001. 166 p.

17. Coenen A, Ryan P, Sutton J. Mapping nursing interventions from a hospital information system to the nursing interventions classification (NIC). Nurs Diagn. 1997;8(4): 145-51.

18. Fehring RJ. Methods to validate nursing diagnoses. Heart \& Lung. 1987;16(6):625-9.

19. Duarte ED, Sena RR, Xavier CC. Processo de trabalho na Unidade de Terapia Intensiva Neonatal: construção de uma atenção orientada pela integralidade. Rev Esc Enferm USP. [periodico na Internet]. set 2009 [acesso 26 mar 2012]; 43(3):647-54. Disponível em: http://www. scielo.br/scielo.php?script $=$ sci_arttext\&pid $=$ S008062342009000300021\&lng=en. http://dx.doi. org/10.1590/S0080-62342009000300021.

20. Batista CG. Concordância e fidedignidade na observação. Psicologia. 1977;3(2):39-49.

21. Nagappan R, Parkin G. Geriatric critical care. Crit Care Clin. 2003;19(2):253-70.

22. Nonino FOL, Napoleão AA, Carvalho EC, Petrilli JF Filho. A utilização do mapeamento cruzado na pesquisa de enfermagem: uma revisão de literatura. Rev Bras Enferm. nov-dez 2008;61(6):872-7.

23. Beglen MA, Goode CJ, Reed L. Nurse Staffing and Patient Outcomes. Nurs Res. 1998; Jan-Feb 47(1):43-50. 24. Seganfredo DH, Almeida MA. Validação de conteúdo de resultados de enfermagem, segundo a Classificação dos Resultados de Enfermagem (NOC) para pacientes clínicos, cirúrgicos e críticos. Rev. Latino-Am. Enfermagem. [periódico na Internet]. fev 2011 [acesso 10 jun 2011]; 19(1): 34-41. Disponível em: http://www. scielo.br/scielo.php?script=sci_arttext\&pid=S010411692011000100006\&lng=pt. http://dx.doi. org/10.1590/S0104-11692011000100006.

25. Garbin LM, Rodrigues CC, Rossi LA, Carvalho EC. Classificação de resultados de Enfermagem (NOC): identificação da produção científica relacionada. Rev Gaúcha Enferm. set 2009;30(3):508-15. 